\title{
Large Scale Production and Crystallization of Acid Carboxypeptidase from Submerged Culture of Penicillium janthinellum, and Stability of the Crystalline Enzyme
}

\author{
Sadaji Yokoyama, Akira Oobayashi, Osamu Tanabe \\ and Eiji ICHISHIMA* \\ Central Research Laboratories, Takara Shuzo Co., Ltd., \\ Setahashimoto, Ootsu, Shiga 520-21 and *Laboratory \\ of Enzymology and Microbiology, Tokyo Nōkō \\ University, Fuchu, Tokyo 183
}

Received November 5, 1974

\begin{abstract}
Acid carboxypeptidase of Penicillium janthinellum IFO-8070 was produced effectively in submerged culture on a medium of $4 \sim 5 \%$ rice bran. The enzyme production was enlarged to volume cultivation of 150 -liters in a 200 -liters jar fermentor, and the yield of acid carboxypeptidase per milliliter filtrate reached to the maximum 3 days after inoculation.

Acid carboxypeptidase of low molecular weight $(\mathrm{M} . \mathrm{W} .=51,000)$ produced in the liquid culture broth was purified and crystallized in a large scale. Purification steps include Amberlite CG-50 treatment, ammonium sulfate precipitation, dialysis using "Diaflow," activated charcoal treatment, and condensation using collodion-bag, or condensation and dialysis using "Diaflow."

The crystals of the acid carboxypeptidase suspended in $50 \mathrm{~mm}$ acetate buffer (pH 3.7) were completely stable for six months at $5^{\circ} \mathrm{C}$. On the other hand, at low enzyme concentration $(0.01 \mathrm{U} / \mathrm{ml})$ in $50 \mathrm{~mm}$ acetate buffer $(\mathrm{pH} 3.7)$, crystallized enzyme was somewhat labile, whereas, this inactivation was completely depressed by covering enzyme solution with toluene.
\end{abstract}

Carboxypeptidases have been isolated and purified from many origins such as Penicillium spp. ${ }^{1 \sim 6)}$ Aspergillus spp., ${ }^{7 \sim 14)}$ bovine pancreas, ${ }^{15,16)}$ citrus fruit and leaves ${ }^{17,18)}$ barley, ${ }^{19,20}{ }^{1}$ French beans, ${ }^{21,22)}$ yeast, ${ }^{23)}$ and cotton seeds. ${ }^{24)}$

Aspergillus acid carboxypeptidase ${ }^{7 \sim 13 \prime}$ has been purified and characterized by Ichishima and co-workers, which had an acidic $\mathrm{pH}$ optimum of 3.1 for the hydrolysis of carbobenzoxy-L-glutamyl-L-tyrosine (Z-Glu-Tyr). $A$. oryzae and $A$. oryzae var. magnasporus produced acid carboxypeptidases which had the same hydrolytic activities toward synthetic substrates but the different $\mathrm{pH}$ optima, molecular weights, and stabilities towards the inhibitors such as $p$-chloromercuribenzoate (PCMB), L-1-tosylamide-2-phenylethyl chloromethylketone (TPCK), monoiodoacetic acid and diisopropylfluorophosphate (DFP). ${ }^{91}$

We previously reported the production and some properties of acid carboxypeptidase of
Penicillium molds in the koji culture. ${ }^{1,2)}$ A low molecular weight $(\mathrm{M} . \mathrm{W} .=51,000)$ acid carboxypeptidase of $P$. janthinellum IFO-8070 produced in wheat bran koji culture was purified 330-fold from koji extract, and crystallized as a disc-electrophoretically homogeneous protein with the recovery of $20 \%{ }^{3}$, Furthermore, we investigated the submerged culture conditions on a small scale $(100 \mathrm{ml})$ and medium composed of wheat bran, defatted soybean, and $\mathrm{KH}_{2} \mathrm{PO}_{4}{ }^{3}{ }^{3}$

In this report, we describe the large scale production of acid carboxypeptidase by $P$. janthinellum IFO-8070 on the liquid medium of $4 \%$ rice bran. Furthermore, we report a large scale purification and crystallization method of the low molecular weight enzyme (M.W. $=51,000)$ produced in this submerged culture, and stabilities of the crystalline enzyme. 


\section{MATERIALS AND METHODS}

Materials. Benzyloxycarbonyl-L-glutamyl-L-tyrosine (Z-Glu-Tyr) was purchased from the Protein Research Foundation, Osaka. Amberlite CG-50 (Type-1) was purchased from Rohm \& Haas (Philadelphia, USA). Other chemicals were obtained commercially.

Organism. Strain used in this experiment is Penicillium janthinellum IFO-8070, ${ }^{1 \sim 3}$ )

Submerged culture on a small scale. A liquid medium of $100 \mathrm{ml}$ prepared from rice bran and wheat bran was used according to the previous paper. ${ }^{33}$

A large scale cultivation. A large scale cultivation was carried out using a 30 -liters jar fermentor equipment (Marubishi Co., Tokyo). $800 \mathrm{~g}$ of rice bran was added to 19.2 liters of tap water and the mixture was adjusted to $\mathrm{pH} 4.0$ with conc. $\mathrm{HCl}$. The medium was sterilized at $121^{\circ} \mathrm{C}$ for $20 \mathrm{~min}$. After inoculation with two slants of spores, a culture was incubated at $25^{\circ} \mathrm{C}$.

Further large scale cultivation was performed using a 200-liters jar fermentor unit (Marubishi Co., Tokyo). $6 \mathrm{~kg}$ of rice bran was added to 144-liters of well water, and the mixture was adjusted to $\mathrm{pH} 4.0$ with conc. $\mathrm{HCl}$. The medium was sterilized at $121^{\circ} \mathrm{C}$ for $20 \mathrm{~min}$, and inoculated with 1.5 liters of seed culture. Cultivation was performed at $25^{\circ} \mathrm{C}$ aerating 75 liters $/ \mathrm{min}$, and agitating as follows: $0 \sim 24 \mathrm{hr} ; 250 \mathrm{rpm}, 24 \mathrm{hr} \sim$; $400 \mathrm{rpm}$. Seed culture was cultivated in 2-liters volume of shaking Erlenmeyer flask containing $500 \mathrm{ml}$ of $4 \%$ rice bran (initial $\mathrm{pH}=4.0$ ) inoculated with one platinum loop of spores. Cultivation was done for 3 days on a rotary shaker $(126 \mathrm{rpm})$ at $27^{\circ} \mathrm{C}$.

Large scale crystallization of acid carboxypeptidase. An outline of the purification step is shown in Table II. Jar fermentation using a 200-liters volume jar fermentor unit was employed twice. The culture broth was filtered through a filter press equipment (Noritake Tekkosho Co., Osaka) at the pressure of about 0.5 $1.0 \mathrm{~kg} / \mathrm{cm}^{2}$. The culture filtrate, 251 liters $(1.40 \mathrm{U} / \mathrm{ml})$, was adjusted to $\mathrm{pH} 3.5$ with conc. $\mathrm{HCl}$, and then was applied to the Amberlite CG-50 (Type-1) column (8.2 $\times 56$ $\mathrm{cm}$ ) equilibrated with 70 liters of $10 \mathrm{~mm}$ acetate buffer ( $\mathrm{pH} 3.5)$. Top of the column was covered by toluene ( $1 \mathrm{~cm}$ depth layer) for preventing from contamination. The column was washed with 70 liters of the starting buffer at a flow rate of 3 liters per hr. The acid carboxypeptidase was then eluted with $0.5 \mathrm{M}$ acetate buffer (pH 5.2). Eluate was fractionated in $20 \mathrm{ml}$ using a fraction collector. Active fractions (Fraction No. 126 $\sim 500$ ) were combined $(6,910 \mathrm{ml})$, and subjected to salting out by the addition of $4.2 \mathrm{~kg}$ of solid ammonium sulfate at $5^{\circ} \mathrm{C}$.
The precipitate was separated by centrifugation $(5000 \times g, 20 \mathrm{~min})$ and dissolved in $700 \mathrm{ml}$ of $50 \mathrm{~mm}$ acetate buffer ( $\mathrm{pH}$ 3.7). Enzyme solution was then centrifuged $(5000 \times g, 20 \mathrm{~min})$ and insoluble substances were discarded. Supernatant was then dialyzed against $50 \mathrm{~mm}$ acetate buffer (pH 3.7) using a "Diaflow" equipment with a two-liters volume of reservoir to remove ammonium sulfate and low molecular weight substances. Furthermore, $14 \mathrm{~g}$ of activated charcoal was added to the dialyzate and the mixture was adjusted to $\mathrm{pH} 3.7$ with $1 \mathrm{~N} \mathrm{HCl}$, and kept to stand for $10 \mathrm{~min}$ at room temperature. The enzyme solution was then filtered through Toyo Roshi No. 5C filter paper to remove charcoal.

$50 \mathrm{ml}$ of the enzyme solution from step 5 in the Table II was concentrated in a collodion-bag in the cold $\left(5^{\circ} \mathrm{C}\right)$. Enzyme crystals (Fig. 3a) appeared within a week. Crystallization could be greatly hastened, however, by seeding the solution with enzyme crystals obtained earlier. Crystals were washed with $50 \mathrm{~mm}$ acetate buffer ( $\mathrm{pH} 3.7$ ) or $5 \mathrm{~mm}$ acetate buffer $(\mathrm{pH} 4.0)$ as the enzyme crystals were almost insoluble at $\mathrm{pH}$ values between 3.5 and 4.5 in these salt concentration.

In another case, $580 \mathrm{ml}$ of the enzyme solution from step 5 was concentrated to about $40 \mathrm{ml}$ and dialyzed in a "Diaflow" equipment against $5 \mathrm{~mm}$ acetate buffer (pH 4.0) using a 2-liters volume of reservoir. Crystallization (Fig. 3b) was allowed to take place as the dialysis was continued for $5 \mathrm{hr}$ or more. Enzyme crystals were washed with $5 \mathrm{~mm}$ acetate buffer ( $\mathrm{pH} 4.0$ ) and stored at $5^{\circ} \mathrm{C}$.

Stabilities of crystalline acid carboxypeptidase. Stabilities of the enzyme at several purification steps were investigated. Enzyme solution was diluted with $50 \mathrm{~mm}$ acetate buffer ( $\mathrm{pH} 3.7$ ) to $0.01 \pm 0.001 \mathrm{U} / \mathrm{ml}$, and $20 \mathrm{ml}$ each was stored in an Erlenmeyer flask $(100 \mathrm{ml}$ volume) or test tube $(16.5 \times 165 \mathrm{~m} / \mathrm{m})$ at $25^{\circ} \mathrm{C}, 5^{\circ} \mathrm{C}$, or $0^{\circ} \mathrm{C}$. $0.5 \mathrm{ml}$ aliquot was pipeted at indicated time, and used directly to the reaction with $0.5 \mathrm{ml}$ portion of Z-Glu-Tyr (pH 3.7).

Acid carboxypeptidase assay. The enzyme was assayed routinely with Z-Glu-Tyr in $50 \mathrm{~mm}$ sodium acetate buffer (pH 3.7).21 One unit of Z-Glu-Tyr hydrolase activity was defined as the amount of enzyme required to liberate $1 \mu$ mole of tyrosine per min at pH 3.7 and $30^{\circ} \mathrm{C}$.

Protein determination. Protein concentration was estimated from the absorbance at $280 \mathrm{~nm}\left(A_{1 \mathrm{~cm}}^{1 \%}=25.4\right)$ using a Hitachi 101 spectrophotometer.

Ultrafiltration. For the concentration or dialysis of enzyme solution, colloidon-bags (Sartorius, Germany) or ultrafiltration unit were used. A "Diaflow" ultrafiltration assembly equipped with a HFA-180 membrane (Abcor, USA) was used for ultrafiltration. 
Disc electrophoresis. Acrylamide gel electrophoresis was performed at $25^{\circ} \mathrm{C}$ with the standard pore formulation of Davis ${ }^{25 !}$ at $\mathrm{pH} 9.4$.

\section{RESULTS}

Submerged production of acid carboxypeptidase

Variation in acid carboxypeptidase production by $P$. janthinellum IFO-8070 in submerged culture is shown in Table I. A medium composed of $3 \%$ rice bran supported substrantial growth and acid carboxypeptidase production (Table I, Expt. 1, 2, and 3). Maximum yield of acid carboxypeptidase per milliliter filtrate $(1.31 \mathrm{U} / \mathrm{ml})$ was obtained with a medium containing $5 \%$ rice bran, and this value was rather higher than that $(1.235 \mathrm{U} / \mathrm{ml})$ obtained in the previous experiment ${ }^{3}$ on a wheat bran: defatted soybean medium (Table I).
In a 30 -liters jar fermentor with $4 \%$ of rice bran, substantial amount of the enzyme (1.00 $\mathrm{U} / \mathrm{ml}$ ) was obtained 3 days after inoculation, and no inactivation of the enzyme was observed when the agitation was changed from $250 \mathrm{rpm}$ to $400 \mathrm{rpm}$ after $48 \mathrm{hr}$ of inoculation (Fig. 1).

Enzyme production with $4 \%$ rice bran could be scaled up to a 200-liters jar fermentor (Fig. 2). The maximum enzyme production $(1.30 \mathrm{U} / \mathrm{ml}$ of filtrate) was reached after $72 \mathrm{hr}$ of inoculation at $25^{\circ} \mathrm{C}$.

In the production of acid carboxypeptidase using the rice bran medium, presterilization could be omitted in the large scale cultivation using 30-, and 200-liters jar fermentors by controlling aeration and agitation (Fig. 1, Fig. 2).

Table I. EFFect of Concentration and Composition of Rice Bran and Wheat Bran on acid Carboxypeptidase Production BY $P$. janthinellum IFO-8070

\begin{tabular}{|c|c|c|c|c|c|}
\hline \multirow{2}{*}{ Expt. ${ }^{a l}$} & \multirow{2}{*}{$\begin{array}{c}\text { Cultivation } \\
\text { times }\end{array}$} & \multicolumn{2}{|c|}{ Concentration of nutrient $(\%)$} & \multirow{2}{*}{$\begin{array}{l}\text { Final } \\
\text { pH }\end{array}$} & \multirow{2}{*}{$\begin{array}{c}\text { Activity } \\
\mathrm{U} / \mathrm{ml}\end{array}$} \\
\hline & & Rice bran & Wheat bran & & \\
\hline 1 & $72 \mathrm{hr}$ & $\begin{array}{l}3.0 \\
2.5 \\
2.0 \\
1.5 \\
1.0 \\
0.5 \\
0\end{array}$ & $\begin{array}{l}0 \\
0.5 \\
1.0 \\
1.5 \\
2.0 \\
2.5 \\
3.0\end{array}$ & $\begin{array}{l}4.26 \\
4.31 \\
4.44 \\
4.59 \\
4.58 \\
5.21 \\
5.03\end{array}$ & $\begin{array}{l}0.773 \\
0.895 \\
0.732 \\
0.893 \\
0.564 \\
0.845 \\
0.466\end{array}$ \\
\hline 2 & $96 \mathrm{hr}$ & $\begin{array}{l}3.0 \\
2.5 \\
2.0 \\
1.5 \\
1.0 \\
0.5 \\
0\end{array}$ & $\begin{array}{l}0 \\
0.5 \\
1.0 \\
1.5 \\
2.0 \\
2.5 \\
3.0\end{array}$ & $\begin{array}{l}4.73 \\
4.73 \\
4.80 \\
4.89 \\
5.00 \\
5.62 \\
5.55\end{array}$ & $\begin{array}{l}0.974 \\
1.000 \\
0.964 \\
0.889 \\
0.807 \\
0.572 \\
0.663\end{array}$ \\
\hline 3 & $120 \mathrm{hr}$ & $\begin{array}{l}3.0 \\
2.5 \\
2.0 \\
1.5 \\
1.0 \\
0.5 \\
0\end{array}$ & $\begin{array}{l}0 \\
0.5 \\
1.0 \\
1.5 \\
2.0 \\
2.5 \\
3.0\end{array}$ & $\begin{array}{l}5.33 \\
5.50 \\
5.51 \\
5.42 \\
5.42 \\
6.21 \\
5.72\end{array}$ & $\begin{array}{l}1.067 \\
1.140 \\
1.023 \\
1.098 \\
0.923 \\
0.675 \\
0.599\end{array}$ \\
\hline 4 & $96 \mathrm{hr}$ & $\begin{array}{r}1.0 \\
2.0 \\
3.0 \\
4.0 \\
5.0 \\
7.0 \\
10.0\end{array}$ & & $\begin{array}{l}4.67 \\
4.61 \\
4.53 \\
4.59 \\
4.50 \\
4.12 \\
4.13\end{array}$ & $\begin{array}{l}0.109 \\
0.605 \\
0.974 \\
1.284 \\
1.310 \\
1.215 \\
0.809\end{array}$ \\
\hline Reference 3) & & \multicolumn{2}{|c|}{$\begin{array}{l}\text { Wheat bran, } 2.0 \% \text {; defatted soybean, } \\
1.0 \% ; \mathrm{KH}_{2} \mathrm{PO}_{4}, 0.2 \% \text {; initial } \mathrm{pH}=5.5\end{array}$} & 6.20 & 1.235 \\
\hline
\end{tabular}

a) The initial $\mathrm{pH}$ was adjusted to 4.0 . 


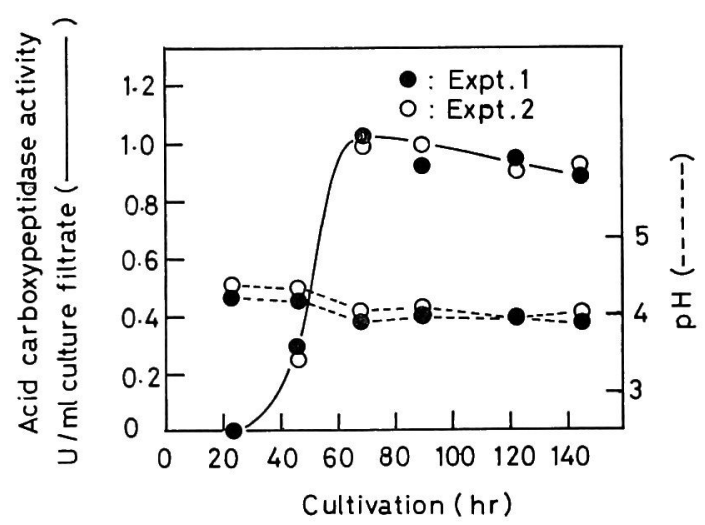

FIG. 1. Enzyme Production by $P$. janthinellum IFO8070 in a 30 -liters Jar Fermentor on the $4 \%$ Rice Bran Medium at $25^{\circ} \mathrm{C}$.

$$
\text { Expt. Cultivation hr }
$$

\begin{tabular}{|c|c|c|c|c|}
\hline $\begin{array}{l}\text { Aeration } \\
\text { (liters } / \mathrm{min} \text { ) }\end{array}$ & $\begin{array}{l}1 \\
2\end{array}$ & $\begin{array}{c}0 \sim 48 \\
5 \\
20\end{array}$ & $\begin{array}{c}48 \sim 71 \\
5 \\
20\end{array}$ & $\begin{array}{r}71 \sim \\
5 \\
28\end{array}$ \\
\hline $\begin{array}{c}\text { Agitation } \\
\text { (rpm) }\end{array}$ & $\begin{array}{l}1 \\
2\end{array}$ & $\begin{array}{l}250 \\
250\end{array}$ & $\begin{array}{l}400 \\
400\end{array}$ & $\begin{array}{l}400 \\
450\end{array}$ \\
\hline
\end{tabular}

When the initial $\mathrm{pH}$ was adjusted to 4.0 , the cultural $\mathrm{pH}$ was almost constant throughout the cultivation, and it was very preferable

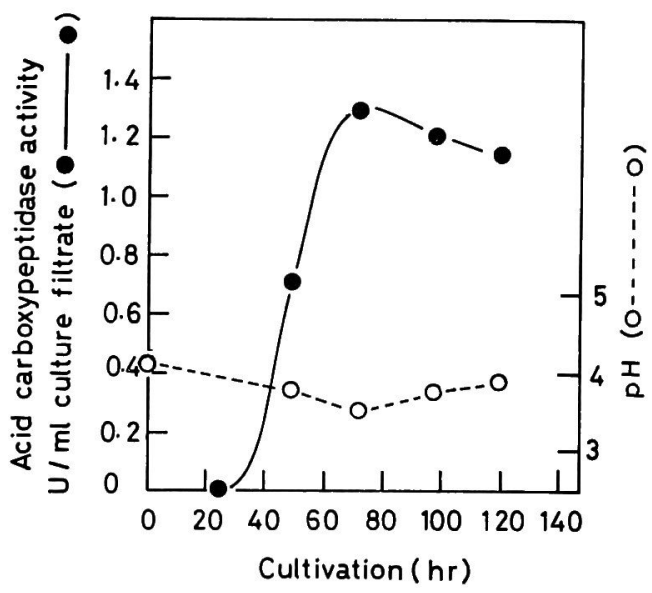

FIG. 2. Enzyme Production by $P$. janthinellum IFO-8070 in a 200 -liters Jar Fermentor on the $4 \%$ Rice Bran Medium at $25^{\circ} \mathrm{C}$.

TAble II. Purification of Acid Carboxypeptidase from $P$. janthinellum IFO-8070

\begin{tabular}{lccc}
\hline \multicolumn{1}{c}{ Step } & $\begin{array}{c}\text { Volume } \\
\text { or } \\
\text { weight }\end{array}$ & $\begin{array}{c}\text { Specific } \\
\text { activity } \\
\left(\mathrm{U} / A_{280}\right)\end{array}$ & $\begin{array}{c}\text { Recovery } \\
(\%)\end{array}$ \\
\hline 1. Culture filtrate & 251 liters & 0.08 & 100 \\
2. Amberlite CG-50 (Type 1) treatment & $6910 \mathrm{ml}$ & 4.40 & 90.6 \\
3. Precipitation by ammonium sulfate & $700 \mathrm{ml}$ & 5.86 & 72.5 \\
4. Dialysis with "Diaflow" & $700 \mathrm{ml}$ & 9.16 & 64.3 \\
5. Activated charcoal treatment & $630 \mathrm{ml}$ & 11.9 & 58.0 \\
6A. Condensation with collodion-bag & $160 \mathrm{mg}$ (1) & 16.5 & 1.76 \\
6B. Condensation and dialysis with "Diaflow" & $1000 \mathrm{mg}$ (a) & 16.5 & 10.8 \\
\hline
\end{tabular}

a) Calculated from specific extinction $\left(A_{1 \mathrm{~cm}}^{1 \%}=25.4\right)$.

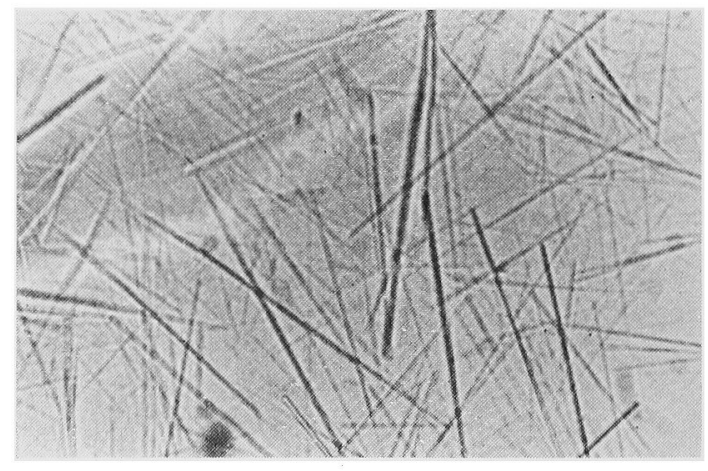

(a)

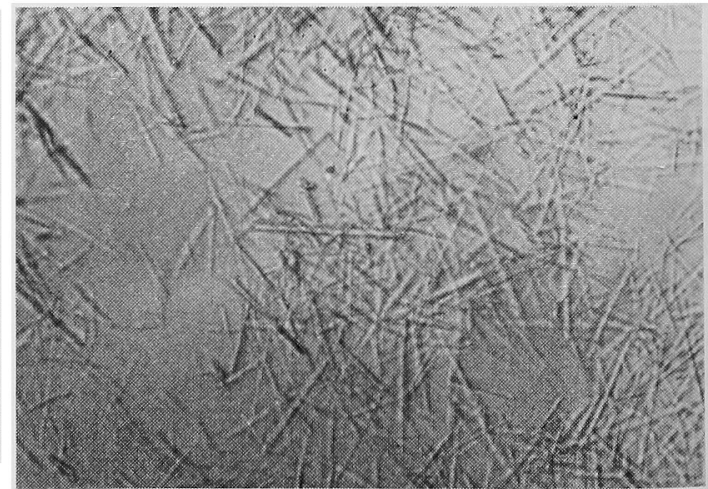

(b)

FIG. 3. Crystals of Acid Carboxypeptidase with Molecular Weight of 51000 from $P$. janthinellum IFO-8070 $(\times 150)$. Details are described in the text. a, collodion-bag method; b, membrane method. 
at the point of stability of the enzyme produced in the medium, and of preventing the liquid culture from contamination. There are almost no foaming throughout the cultivation, and antifoaming reagent was unnecessary. Since this fungus forms filamentous mycelia when grown in this medium under these aeration and agitation conditions described in the text, filtration of culture broth can be efficiently accomplished, in a laboratory scale, by vacuum filtration through Toyo Roshi No. 2 filter paper. Use of a filter press equipment is desirable when hundreds of liters are to be treated.

\section{Large scale preparation of crystalline enzyme}

Large scale pruification and crystallization include Amberlite CG-50 treatment, ammonium sulfate precipitation, dialysis using "Diaflow," activated charcoal treatment, and condensation using a collodion-bag or condensation and dialysis using "Diaflow" (Table II). Crystallization with a collodion-bag or "Diaflow" produced the same type of needleshaped crystals (Fig. $3 \mathrm{a}$ and $3 \mathrm{~b}$ ), and both crystalline preparations had the same specific activity of $16.5 \mathrm{U}$ (Table II). These crystalline acid carboxypeptidases were disc-electrophoretically homogeneous at $\mathrm{pH} 9.4$ same as the crystals ${ }^{3)}$ obtained from koji culture.

\section{Stabilities of the acid carboxypeptidase}

The crystals of acid carboxypeptidase suspended in $50 \mathrm{mM}$ acetate buffer ( $\mathrm{pH}$ 3.7) were completely stable in six months at $5^{\circ} \mathrm{C}$ (Table III). Furthermore, no loss of enzyme activity was observed when the crystallized enzyme solution of $0.5 \mathrm{U} / \mathrm{ml}$ was stored at $25^{\circ} \mathrm{C}$ for $96 \mathrm{hr}$ (Table III). When the enzyme concentration was $0.1 \mathrm{U} / \mathrm{ml}$, the crystallized enzyme was considerably stable on the storage at $25^{\circ} \mathrm{C}$ (Table III). The enzyme was, however, somewhat labile when diluted with $50 \mathrm{~mm}$ acetate buffer (pH 3.7) to such a low concentration as $0.01 \pm 0.001 \mathrm{U} / \mathrm{ml}$, and in this case, more than $80 \%$ of the enzyme activity was lost after incubation at $25^{\circ} \mathrm{C}$ for $48 \mathrm{hr}$ (Table III). On the storage at low temperature $\left(5^{\circ} \mathrm{C}\right.$ or $\left.0^{\circ} \mathrm{C}\right)$, the crystallized enzyme was a little more stable than that at $25^{\circ} \mathrm{C}$ (Table III).

Inactivation of enzyme solution in low concentration $(0.01 \pm 0.001 \mathrm{U} / \mathrm{ml})$ could be completely retarded by covering surface of the solution with toluene, and in this case, the enzyme solution showed no loss of the activity within 8 days at $25^{\circ} \mathrm{C}$ (Table IV). Dilution of the enzyme with boiled and vacuumpacked buffer solution was rather preferable to prevent enzyme inactivation (Table IV).

Addition of $10 \mathrm{mM}$ L-ascorbic acid as an

Table III. Stabilities of Crude and Crystalline Preparations of Acid Carboxypeptidase AT pH 3.7

\begin{tabular}{|c|c|c|c|c|c|c|c|c|c|}
\hline \multirow{2}{*}{ Enzyme preparation from } & \multirow{2}{*}{$\begin{array}{l}\text { Stored at } \\
(\mathrm{C})\end{array}$} & \multicolumn{8}{|c|}{ Residual activity $(\%)$} \\
\hline & & $0 \mathrm{hr}$ & $5 \mathrm{hr}$ & $10 \mathrm{hr}$ & $24 \mathrm{hr}$ & $48 \mathrm{hr}$ & $72 \mathrm{hr}$ & $96 \mathrm{hr}$ & 6 month \\
\hline Culture filtrate (Step 1$)^{a}$ & 25 & 100 & 98 & 105 & 91 & 94 & & & \\
\hline Amberlite CG-50 (Step 2) & 25 & 100 & 99 & 94 & 90 & 77 & & & \\
\hline Dialyzate (Step 4) & 25 & 100 & 90 & 87 & 93 & 77 & & & \\
\hline Crystals (Step 6B) ${ }^{a}$ & 25 & 100 & 63 & $47 \sim 67$ & $15 \sim 38$ & $0 \sim 18$ & & & \\
\hline Crystals (Step 6B) ${ }^{a \prime}$ & 5 & 100 & - & 87 & 60 & 37 & & & \\
\hline Crystals (Step 6B) ${ }^{a \prime}$ & 0 & 100 & - & 76 & 75 & 50 & & & \\
\hline Crystals (Step 6B), $0.1 \mathrm{U} / \mathrm{ml}^{b}$ & 25 & 100 & - & 一 & 71 & 66 & 57 & 55 & \\
\hline Crystals (Step $6 \mathrm{~B}$ ), $0.5 \mathrm{U} / \mathrm{ml}^{b}$ & 25 & 100 & - & 一 & 104 & 111 & 106 & 103 & \\
\hline Crystal suspension (Step 6A) ${ }^{c 1}$ & 5 & 100 & - & - & - & - & - & - & 100 \\
\hline
\end{tabular}

a) Enzyme solution was diluted with $50 \mathrm{~mm}$ acetate buffer (pH 3.7) to about $0.01 \pm 0.001 \mathrm{U} / \mathrm{ml}$, and stored at indicated temperature.

b) Enzyme solution was diluted with $50 \mathrm{~mm}$ acetate buffer ( $\mathrm{pH} 3.7$ ) to $0.1 \mathrm{U} / \mathrm{ml}$ and $0.5 \mathrm{U} / \mathrm{ml}$, and stored at $25^{\circ} \mathrm{C}$.

c) Enzyme crystals were suspended in $50 \mathrm{~mm}$ acetate buffer, and stored at $5^{\circ} \mathrm{C}$. 
Table IV. EFfect of Toluene and L-Ascorbic Acid on the Stability of $P$. janthinellum IFO-8070 ACID CARBOXYPEPTIDASE

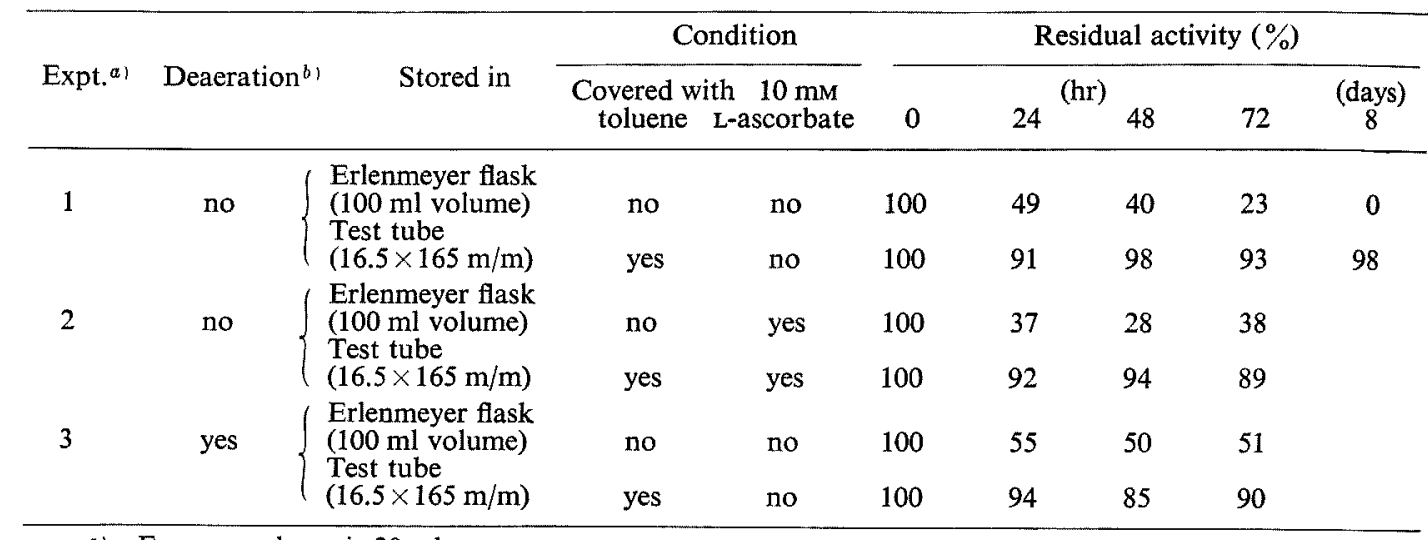

a) Enzyme volume is $20 \mathrm{ml}$

b) $50 \mathrm{~mm}$ acetate buffer $(\mathrm{pH} 3.7)$ to be used to dilute enzyme solution was boiled for $30 \mathrm{~min}$ and aspirated for $1 \mathrm{hr}$ before use.

antioxidant had no appreciable protecting effect on the enzyme activity (Table IV). $10 \mathrm{mM} \mathrm{SH}$-reagents such as 2-mercaptoethanol (2-ME) and dithiothreitol (DTT) had no retarding effect on the inactivation. $0.4 \mathrm{M} \mathrm{KCl}$ and $1 \mathrm{M}$ sucrose also showed no preventing effect on the enzyme inactivation at low enzyme concentration $(0.01 \pm 0.001 \mathrm{U} / \mathrm{ml})$.

\section{DISCUSSION}

We now observed high acid carboxypeptidase production on the rice bran medium, and the maximum enzyme production (1.31 $\mathrm{U} / \mathrm{ml}$ ) was observed $96 \mathrm{hr}$ after inoculation. Production of acid carboxypeptidase could be enlarged to 30-liters and 200-liters volume jar fermentor unit.

The rice bran medium has many advantages in the industrial scale, such as low cost of material, readily for sterilization, unnecessary of antifoaming reagent and $\mathrm{pH}$ control during the enzyme production, and readily for filtration of mycelia. Acid carboxypeptidase produced by $P$. janthinellum IFO-8070 was almost completely adsorbed onto the Amerlite CG-50 column, and easily eluted with $0.5 \mathrm{M}$ acetate buffer (pH 5.2). Through this procedure, the culture filtrate was condensed to one 40th and was purified 55-times in specific activity (Table II).
We previously obtained $15 \mathrm{mg}$ of crystalline acid carboxypeptidase of low molecular weight $(\mathrm{M} . \mathrm{W} .=51,000)$ from 1.5 liters koji extract. ${ }^{3)}$ Purification method included ammonium sulfate precipitation. Amberlite CG-50 chromatography, dialysis, acetone fractionation, Amberlite CG-50 rechromatography, and condensation in a collodion-bag. ${ }^{3)}$ However, column chromatography was laborous and was not proper for large scale enzyme preparation. We investigated a simple purification method from the submerged culture filtrate.

Purification procedure summarized in Table II is very suitable for the large scale preparation of crystalline enzyme. Successful crystalline preparation (Fig. $3 \mathrm{a}$ and $3 \mathrm{~b}$ ) was made. Condensation by collodion-bag forms the same type of crystals (Fig. 3a) as that obtained from koji culture previously, ${ }^{3)}$ on the other hand, condensation and dialysis by "Diaflow" forms smaller crystals (Fig. 3b). Crystalline enzyme from a liquid culture was eluted from the Sephadex G-75 column at the same elution volume as that of crystalline enzyme purified from a solid koji culture, indicating that both enzyme preparation have the same molecular weight $(51,000)$. These crystalline enzyme purified from solid and liquid cultures showed the same specific activity of $16.5 \mathrm{U}$, 
and a single protein band on disc-electrophoresis at $\mathrm{pH} 9.4$ gel.

Since partially purified acid carboxypeptidases of Penicillium molds have been recognized to be stable at the $\mathrm{pH}$ between 3 and $7,{ }^{2)}$ stabilities were investigated at $\mathrm{pH} 3.7$. In a crude preparation, acid carboxypeptidase was stable at $25^{\circ} \mathrm{C}$ even in the low concentration of $0.01 \pm 0.001 \mathrm{U} / \mathrm{ml}$, whereas, the crystalline enzyme was somewhat labile under the same condition. At low temperature $\left(5^{\circ} \mathrm{C}\right.$ or $0^{\circ} \mathrm{C}$ ), the inactivation was partially retarded. Furthermore, covering surface of the enzyme solution with toluene completely protected the enzyme activity from inactivation. These phenomena seem to indicate the oxidative denaturation of the diluted enzyme solution.

The previous inhibition studies ${ }^{2}$ suggested that a thiol group is in or very near the active site of the acid carboxypeptidase. Whereas, antioxidant of L-ascorbic acid and SH-protecting reagents of 2-mercaptoethanol (2-ME) and dithiothreitol (DTT) showed no protecting effect in the present experiments.

\section{REFERENCES}

1) S. Yokoyama and E. Ichishima, Agr. Biol. Chem., 36, 1259 (1972).

2) S. Yokoyama, A. Oobayashi, O. Tanabe, S. Sugawara, E. Araki and E. Ichishima, Appl. Microbiol, 27, 953 (1974).

3) S. Yokoyama, A. Oobayashi, O. Tanabe and E. Ichishima, ibid., 28, 742 (1974).

4) R. Shaw, Biochim. Biophys. Acta, 92, 558 (1964).

5) S. R. Jones and T. Hofmann, Can. J. Biochem., 50, 1297 (1972).
6) A. Hui, L. Rao, A. Kurosky, S.R. Jones, G. Mains, J. W. Dixon, A. Szewczuk and T. Hofmann, Arch. Biochem. Biophys., 160, 577 (1974).

7) E. Ichishima, Proc. Agr. Chem. Soc. Jap., 44, 55 (1969).

8) E. Ichishima, Biochim. Biophys. Acta, 258, 274 (1972).

9) E. Ichishima, S. Sonoki, K. Hirai, Y. Torii and S. Yokoyama, J. Biochem., 72, 1045 (1972).

10) E. Ichishima, A. Yamane, T. Nitta, M. Kinoshita, S. Nikkuni, T. Oka and S. Yokoyama, Appl. Microbiol., 26, 327 (1973).

11) E. Ichishima and T. Arai, Biochim. Biophys. Acta, 293, 444 (1973).

12) E. Ichishima and K. Yomogida, Agr. Biol. Chem., 37, 693 (1973).

13) T. Arai and E. Ichishima, J. Biochem., 76, 765 (1974).

14) T. Nakadai, S. Nasuno and N. Iguchi, Agr. Biol. Chem., 36, 1343, 1473, 1481 (1972).

15) P. H. Pétra, "Methods in Enzymology," Vol. XIX, ed. by G. E. Perlmann and L. Lorand, Academic Press Inc., New York, 1970, p. 460.

16) J. E. Folk, K. A. Piez, W. R. Carroll and J. A. Glandner, J. Biol. Chem., 235, 2272 (1960).

17) H. Zuber, Nature, 201, 613 (1964).

18) B. Spróssler, H.-D. Heilmann, E. Grampp and H. Uhlig, Hoppe-Seyler's Z. Physiol. Chem., 352, 1524 (1971).

19) K. Visuri, J. Mikola and T.-M. Enari, Eur. J. Biochem., 7, 193 (1969).

20) M. Moeller, G. S. Robbins, W. C. Burger and N. Prentice, J. Agr. Food Chem., 18, 886 (1970).

21) J. R. E. Wells, Biochem. J., 97, 228 (1965).

22) W. F. Carey and J. R. E. Wells, J. Biol. Chem., 247, 5573 (1972).

23) R. Hayashi, S. Moor and H. Stein, ibid., 248, 2296, 8366 (1973).

24) J. N. Ihle and L. S. Dure III, ibid., 247, 5034 (1972).

25) B. J. Davis, Ann. N.Y. Acad. Soc., 121, 404 (1964). 